PART 2

Genomics and Rethinking Human Nature 
Aasim I. Padela - 9789004392137

Downloaded from Brill.com04/26/2023 11:02:10AM via free access 


\title{
Conceptualizing the Human Being: Insights from the Genethics Discourse and Implications for Islamic Bioethics
}

\author{
Aasim I. Padela
}

\section{Introduction ${ }^{2}$}

Bioethics is a complicated field of inquiry. For one, its subject matter is vast as the "bio-" in bioethics pertains to a broad range of human activities involving the biomedical sciences such as clinical care, research, and policy-making. At the same time, the "-ethics" part of the term brings in multiplicity as it draws in many different moral theories and reasoning modalities utilized by experts to assess the morality of practices and policies relevant to biomedicine. In addition, bioethics as a field of study breeds further variety as it engages multi- and inter-disciplinary perspectives on any particular issue. Consequently, reflecting a field that sits at the interface of many different areas of knowledge, and a discipline that has ambiguous boundaries, bioethics discourse is complex and multi-faceted.

Although there are a great number of issues discussed in the bioethics literature and a great number of disciplinary experts offer perspectives on these issues, contemporary bioethics discourse fundamentally deals with the ethical (and legal) issues that arise from the interaction of the biomedical sciences with society. Thus bioethicists, in their normative mode, make claims about to

1 Aasim I. Padela, MD MSc, The University of Chicago, 5841 S Maryland Ave, MC 5068, Chicago, IL 6o637 USA, apadela@uchicago.edu

2 Deep gratitude is due to Dr. Mariel Kalkach Aparacio who assisted in the conduct of this research project. The author also expresses gratitude to Profs. Oliver Leaman Hub Zwart for their insightful review of earlier versions of this manuscript and to participants in the seminar at which it was presented. This paper was presented at the Islamic Ethics and the Genome Question Seminar at the Research Center for Islamic Legislation and Ethics (CILE) in Doha, Qatar in April 2017.

(C) AASIM I. PADELA, 2019 | DOI:10.1163/9789004392137_006

This is an open access chapter distributed under the terms of the prevailing CC-BY-NC License at the time of publication. 
how we ought to behave and structure society. Yet in as much as bioethicists (and bioethics discourse in general) speak to the ethico-legal, they also comment, directly or indirectly, on the ontological. Arguably, the identification of a bioethical problem, the framing of the dimensions of that problem, the ethical concepts deployed to work through the problem, and even the interpretation of the biomedical science or technology that is at the center of the problem are connected to understandings of what sorts of things human beings are. In other words, ontological claims about the nature of things can be carried with bioethical arguments.

By way of example consider the moral assessment of a physician intentionally acting against a patient's informed and voluntary decisions about healthcare. One may formulate ethical problem(s) in many different ways, and use various philosophical concepts to solve the problem. For some the dominant issue is the harm to a patient inflicted by an undesired therapy (a patient focus), others may consider the core issue to be the lack of respect accorded to a patient's choice (a focus on the relationship between patients and doctors), and still others may consider the physician's paternalism to be morally objectionable (a focus on the physician). Clearly all of these different vantage points are related. Yet, the starting point for analyses and the accompanying ethical concepts invoked can belie an ontological claim about the nature of patients. Illustratively, a version of that claim could proceeds as follows: Patients are persons, and persons are members of the human species. Humans, in turn, are living organisms with a certain set of distinguishing capacities (or essential features) that include the potential for ratiocination and will making. These capacities are realized when making healthcare decisions. Physicians likewise are humans and equivalent to patients in essence. Therefore, all else equal, acting against a patient's will is wrong because it disrespects the essence of the patient. Another formulation might invoke the notion of humans being endowed with dignity, and that having dignity differentiates things that cannot be instrumentalized from things that can be. Consequently, should a physician intentionally act against a patient's informed and voluntary decision they are, in effect, instrumentalizing the patient in the pursuit of an interest that the patient has rejected. Consequently, the patient's dignity has been assaulted. The point here is not the logic of these claims, rather it is to highlight that ontologies of the human can undergird bioethical views. Within the discourse these ontologies might be implicit or unspoken but can be nonetheless fundamental.

As a result, religious scholars engaging with the contemporary (and largely secular) bioethics discourse need to not only understand the biomedical science and technology involved with the moral issue at hand and the socie- 
tal and legal implications of that science and/or technology, but also need to evaluate whether particular ontologies are impressing upon ethical arguments presented in the discourse. If a "secular" ontology prefigures ethical debates, scholars of religion may need to address that ontology alongside the ethics of the matter because religious ontologies can shape distinctive moral worldviews.

With this thesis as an introduction, this paper presents several ontologies of the human that inhabit the "genethics" literature. ${ }^{3}$ These ontologies were identified through qualitative content analyses of a systematic literature review of the bioethics literature. Prior to discussing these methods and our findings (the ontologies), a few provisos are in order. First there is considerable debate as to whether ontology precedes ethical deliberation, or whether ethical notions are contained within social structures that define relationships between beings. In other words do (and must) we know what and whom we are before defining ethical obligations related to other entities, or do ethical obligations define us even before we recognize who and what we are. This debate is found within the medical ethics literature where some bioethicists ground theories of medical ethics within ontologies of the living body (Pellegrino and Thomasma 1981), and others hold that a moral philosophy for medicine starts with a "living heteronomy (that) constitutes the basis of patient-physician relation..." (Tiemersma 1987, 133). This paper operates out of the view that ontology and ethics are related, and that for religious traditions (particularly Islam) this linkage is important and fundamental. However the paper does not assert that ethics and ontology must always be related, or that all of the contemporary bioethics literature proceeds from ontological claims. Thus those seeking to find the bioethical literature replete with discussions on ontology will be disappointed, as will those seeking to find this paper to offer plentiful snippets of text demarcating how ontology informs the ethical in genethics debates. Rather this paper presents conceptualizations of the human being that emerged during our examination (details below) of the bioethics literature; that can be theorized up from the bioethical deliberation contained therein. Our study further proposes that connections between ontology and ethical concepts can

3 Genethics initially referred to "the study of the ethical issues that arise out of the science of genetics and the uses of genetic technologies" but presently also encompasses ethical issues relating to genomics. See BM Knoppers. From medical ethics to genethics. Lancet 2000:356, T Lewens. What is genethics? J Med Ethics 2004(30): 326-328, D Heyd. Genethics: Moral Issues in the Creation of People, University of California Press 1992. J Burley and J Harris (eds). A Companion to Genethics. Blackwell Publishing 2004. 
reasonably be inferred, even if these links are subliminal to the authors of specific articles. We will demonstrate these particulars below.

Another important point is that the paper asserts that the Islamic tradition has distinctive ways of explaining reality, describing relationships between human beings and other entities, and of moral reasoning. To be sure there is no singular Islam; Islamic theological doctrines and ethico-legal schools are many and a pluralistic orthopraxy constitutes the intellectual tradition. Yet as a tradition that is distinguished from other systems of thought and practice by its scripture and authority structures, one can make claims about there being "Islamic" theological, ethical, and ontological frameworks. While the hallmarks of an "Islamic" system can be debated, and a multiplicity of "Islamics" may be advanced, the paper contends there to exists Islamic worldviews arising out of its scriptural texts. This claim bears underscoring because this paper discusses ontologies of the human and one might argue that the reality of the human being is singular and shared by religious adherents and secularists alike. Our point is not to suggest that there are different types of humans inhabiting the earth some Islamic and some not, rather that the Islamic tradition might offer descriptions of human nature and its essence that are in some way distinctive and different, and that these differences are morally significant for genethics discourses.

Bearing these qualifications in mind, the paper proceeds as follows. The next section details the sources of study and methods by which these ontologies were identified. The subsequent section discusses how the ethical terms and concepts contained within articles match up with a particular ontological stance about the human being. The final section of the paper outlines how these ontologies implicate Islamic theology and ethics, and outlines critical questions Islamic bioethicists must address as they provide Islamic perspectives on genetic and genomic interventions.

\section{Sources and Methods}

Several standard social scientific methods common to health research, each with their particular research aim, were utilized in this study. First, a systematic literature review was conducted to identify the major themes and topics of the genethics discourse. Once the ethics topics and concepts were thematically grouped, qualitative content analytic methods were used to identify potential ontologies that could provide explanatory links between ethics concepts and discussion themes (Miles and Huberman 1994, Crabtree and Miller 1999, Corbin, Strauss, and Strauss 2008). Greater details are provided below. 


\section{Literature Search Strategy}

The genethics discourse is vast, contains multiple different sources for study, and a variety of research approaches can be taken to canvass the discourse. Our primary goal was to identify the major topics of discussion (domains) within the genethics literature, and to catalog the ethical concepts deployed in these debates. Accordingly a systematic literature review was undertaken as a method to capture scholarly discussions among bioethicists. We decided to focus upon journal articles because these are often more timely and contain more concise arguments than books, and are more scholarly than public pieces. Furthermore the MEDLINE database was purposively selected because it contains the greatest number of peer-reviewed journal articles on the life sciences, is globally accessible, and is the primary literature source for clinicians, biomedical researchers, and bioethicists (Falagas et al. 2008)

The OVID interface was used to carry out a systematic literature review of MEDLINE on December 19th 2016. A conjunction of two search terms was used to retrieve pertinent articles, the first term representing genomics/genetics, and the second term restricting articles to those contained within leading bioethics journals. These terms were combined using the Boolean operator "and." Specifically "genomics" as the first term was exploded using MESH headings, keywords, and subheadings to include the following terms "genomics", "genetic therapy", "genetics", "human genome project", "gene therapy" and" genetic research." All of these terms were entered into the search string using the Boolean operator "or". Also using the Boolean operator "or" the second search term limited the literature retrieval to articles contained within the top ten bioethics journals according to the $\mathrm{h}_{5}$-index score. These journals were the Journal of Medical Ethics, the American Journal of Bioethics, Journal of Bioethics, the Hastings Center Report, BMC Medical Ethics, the Journal of Clinical Ethics, Cambridge Quarterly of Healthcare Ethics, the Kennedy Institute of Ethics Journal, the Journal of Bioethical Inquiry, and Theoretical Medicine and Bioethics. We restricted the search to these leading bioethics journals in order to capture an "in-group" conversation among bioethicists, although we acknowledge that journals focused on the science and practice of genomics and genetics likely contain ethical debates as well. Finally, for reasons of practicality the search was also restricted to articles published in the past 5 years and in the English language.

\section{Literature Review}

After completing the MEDLINE search, two researchers independently reviewed manuscript titles and abstracts for relevance- the primary focus of the paper had to be on ethical issues related to genetics and genomics. Accord- 
ingly, book reviews, editorial introductions to special volumes, animal studies, and historical articles were removed from the database, as were duplicate titles. Articles without abstracts were automatically placed into database for full-text review. With this final list of articles for full-text review, the two researchers jointly developed a standard abstraction instrument that classified articles by type (empirical study, case report, bioethical analysis, literature review, commentary, and other).

Moving from conventional systematic literature review methods to a more qualitative grounded-theory based content analysis approach, data abstraction also involved "open coding." (Strauss and Corbin 1998). The two researchers independently described several paper characteristics through open coding including the principal ethical question or topic(s) addressed by the paper and the ethical concepts deployed within the arguments. Each of these labels applied by the researchers functioned as qualitative "codes" for subsequent qualitative analysis.

In order to assure consistency of data abstraction a set of ten abstracts and articles was independently reviewed and "double coded" by the researchers. Discrepancies in data abstraction were resolved by consensus. Subsequently, each researcher independently reviewed approximately half of the remaining abstracts and articles. Combining the two researcher's databases created a final database containing the bibliographic and abstraction data.

\section{Development of Findings}

While standard qualitative analysis techniques were used to develop our findings (described below), our approach was also inspired by a critical discourse analysis (CDA) theory. While there are many different ways in which CDA is applied in research and many different techniques, at the core of strategies is an acknowledgement of discourse being both socially constructed and socially conditioned. CDA seeks to make "visible the interconnectedness of things" in order to open up understandings of how social practices inform dominant forms of language use and marginalize others, and emphasizes multidisciplinary approaches (Wodack and Meyer 2009, Fairclough 2009).

Although we do not perform the sorts of in-depth textual and semiotic analyses often used by those employing CDA (we used qualitative analyses methods instead) our project applies a CDA lens to unpacking the often-implicit conceptualizations of the human that undergird the genethics literature. To be sure, we view contemporary bioethics discourse as social constructed and conditioned for it advances ethical pluralism and operates under secular conventions that privilege philosophy over theology, and reason-based arguments over scriptural-based hermeneutics. Our qualitative content analyses sought 
to make visible the connections between ethical concepts and genethics-related domains of study and fundamental ontologies regarding the human. Finally, we bring multidisciplinary approach to our development of findings for both researchers are situated in multiple bioethics-related practices. Both are practicing clinicians, bioethics researchers, participate in ethics committees, and both have deep religious commitments (MKA is Catholic Christian, and AIP Sunni Muslim).

As noted above the data abstraction instrument allowed the researchers to apply codes representing the principal ethical questions of and ethical concepts mentioned within the papers. For example one article might be entered in the database as focused on analyzing whether parents have a duty to select the best genetic traits for their children (principal question), and used the concepts of beneficence and Parfit's grounds for complaint principle to offer its argument (ethical concepts). Based on these codes the researchers sought to develop higher-order themes to classify the articles by topic of study. Based on consensus the bioethical topics discussed by the papers were grouped into six higher-order domains of study [plus an other category as detailed below], and each article was subsumed under one of these domains via researcher consensus. Once these domains were identified, the next task was to assess relationships between the open-coded ethical concepts, the principal questions of the article, and the domain. In conventional qualitative methods terminology, we were using a grounded theory approach to develop an overall conceptual link between all of the codes within a particular domain. We hypothesized that this link, if present, would represent a specific ontology of the human. In other words, the analyses sought to identify how all of the ethical concepts and questions contained within the articles within that particular domain conveyed a distinctive conceptualization of the human being.

\section{Results}

\section{Descriptive Results of the Systematic Literature Review}

277 articles were retrieved from MEDLINE, and after discarding duplicates, book reviews, editorial introductions to special volumes, animal studies, historical articles and articles not relevant to genethics, 203 unique articles underwent data abstraction [See Figure 1]. These articles could be grouped into six domains of ethical study: (1) Information Disclosure \& Data-Ownership, (2) Human Enhancement \& Modification, (3) Ethical Structures \& Moral Responsibility in Genomics Research, (4) Human Reproduction Related-Ethics, (5) Special Considerations for Research in Vulnerable Communities and Popula- 
tions, (6) Environment \& Epigenetics. Articles not fitting within these domains were marked as "other."

Most articles $(\mathrm{n}=108)$ related to Information Disclosure and Data-Ownership and covered bioethical issues such as the ethics of conveying incidental findings, and notions of ownership of data in bio banking. The next most represented category was Human Reproduction Related Ethics $(n=16)$ in which articles discussed moral issues related to reproductive cloning, gender and trait-selection in the to-be-born, and other bioethical issues related to pre-implantation genetic diagnoses. Human Enhancement \& Modification and Special Considerations for Research in Vulnerable Communities \& Populations comprised of a nearly equal number of articles (10 and 11 respectively), and these domains covered articles discussing issues such as the genetic enhancement and the cultural significance of genetic data in minority communities. Eight articles were placed into category 3 and pertained to ethical structures such as informed consent, while 5 articles detailed bioethical issues related to epigenetics and the environment.

As the ethical concepts discussed by, and principal questions of, the articles were linked to specific domains, three ontologies of the human were found to underlie three domains. These ontologies can subsume all of the ethical concepts and questions contained within a particular domain. The articles within the Information Disclosure and Data-Ownership appear to conceptualize the human being as a source of information about the past, present, and future and the ethical arguments and questions pertain to this ontology. The discussions contained within the domain of Human Reproduction-Related Ethics revolve around the ontology of a human as a being whose essence is defined by the capacity to reproduce. Undergirding the ethical concerns contained within the articles about Human Enhancement and Modification was the vision of a human being as an ever-evolving entity.

In what follows we will describe these ontologies with reference to the ethical concepts and questions dealt with by individual articles (in qualitative methods terms we will describe the codes and links). Our intention, however, is not to describe all of the articles along with all of the associated ethical concepts and questions, rather it is to describe the ontologies in sufficient enough terms so as to evidence the validity of our findings. 

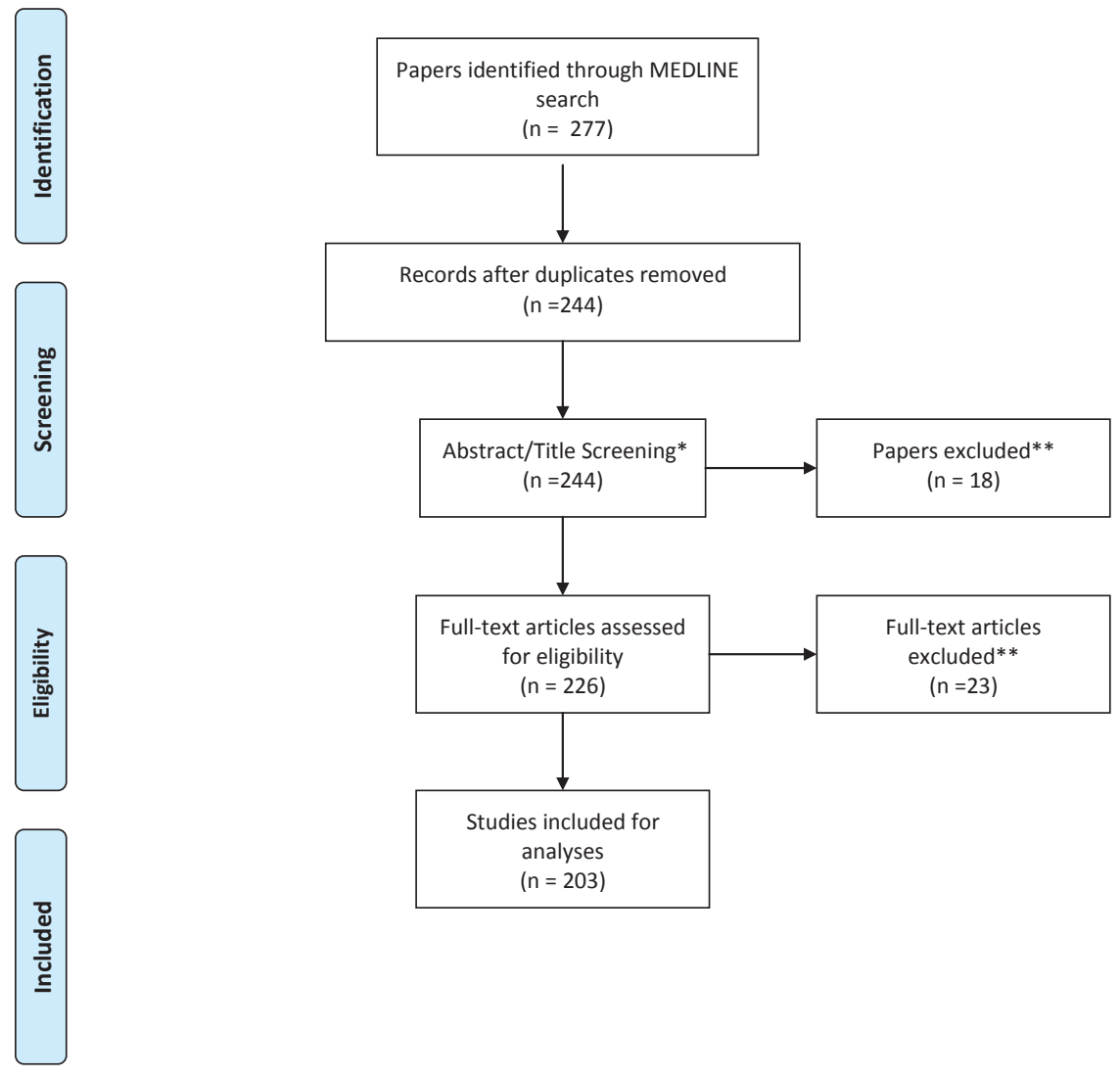

FIGURE 1: Genethics Literature Review Flow Diagram

(ADAPTED FROM: MOHER D, LIBERATI A, TETZLAFF J, ALTMAN DG, THE PRISMA GROUP (2009). PREFERRED REPORTING ITEMS FOR SYSTEMATIC REVIEWS AND META-ANALYSES: THE PRISMA STATEMENT. PLOS MED 6(7): E1000097. DOI:10.1371/JOURNAL. PMED1000097)

* $\quad 98$ articles without abstracts were automatically carried through to full-text review

** Exclusion criteria were same for both stages as outlined in the methods section 


\section{The Human Being as a Source of Information about the Past, Present, and Future}

Genes are segments of DNA within chromosomes, which assist in the production of proteins that are critical to the physiological functioning of an organism. In a sense, genes are the instruction manuals by which organisms develop, grow, maintain themselves, and reproduce because they contain the blueprint for all proteins needed by a cell. These proteins then play a role in all functions of the body. Genes are also integral to human heredity as they are passed down from parents to children in chromosomes contained within male and female gametes (sex cells). In this way parents and children bear resemblance to one another physically and psychologically, and rare disorders can afflict members of a family because of their similar genetic composition. Given the critical role genes play in the existence, maintenance, and propagation of human life the popular notion that genes make us who we are is understandable.

Given the important role genes play in generating the human being, and their importance in passing on information from one generation to the next, the ontology of a human being as a data store that houses information about the past, present and future is implicit in the genethics literature. This conceptualization prefigures bioethical questions and concepts related to genetic and genomic technologies. The genetic code contained within human cells provides information about the past in that it reveals ancestral linkages, e.g. paternity. It contains data about the present because it reveals data about a person's present physiological and psychological state and disorders that may be present. Genetic data also reveals dispositions and likelihoods related to future disease. In a sense then, genes contain essential knowledge about humans, individually and collectively, relevant to the past, present and future.

When the human being is seen as a repository of such information, it follows that ethical concerns revolve around the moral duties related to protecting, and regulating, the use of these data. To begin with bioethicists debate ownership because the information gleaned from genes is relevant not only to the individual it was procured from, but also to other individuals such as relatives and children because of the shared genetic composition. Such debates were found in many different articles (Dheensa, Fenwick, and Lucassen 2016, Rothstein 2013, Milner, Liu, and Garrison 2013). For example, in their interviews of patients, Dheensa and colleagues found that participants perceived "genetic information as essentially familial;" in the words of one participant shared "this isn't my information, I don't own the gene." (Dheensa, Fenwick, and Lucassen 2016, 2). This view was based on the idea that relatives "have a right to know about their potential risks" for disease, and that patients and clinicians 
have a moral duty to disclose pertinent information provided sufficient potential for significant harms exist. (Dheensa, Fenwick, and Lucassen) Notably, participants introduced some ambiguity by viewing genetic information related to one's own day-to-day health to be personal and not communal (Dheensa, Fenwick, and Lucassen 2016).

While Dheensa's paper presents qualitative data pertaining to the moral duties of disclosure, other articles present direct normative arguments. The standard view regarding genetic data is that they "belong" to the individual that supplied the physical material from which they were gleaned. The ownership relationship coheres with the ontology of a human as a data-store where genes are its inner core. Accordingly, usage of the data requires authorization from the individual. Bioethicists assessed whether forgoing individual consent in order to disclose genetic information to the other individuals is legitimate. For example the reflection of a moral "duty to warn" relatives that have a genetic marker for disease into legal structures was analyzed by Weaver (2016). She asserts that physicians' "ethic of care" can help inform professional standards and reconcile legal statues so that a particular patient's consent might not be necessary for disclosing risks of disease to that patient's relatives (Weaver 2016). Similarly a series of articles discussed the ethics of re-contacting the family members of a deceased research participant in order to convey genetically determined risks for disease (Milner, Liu, and Garrison 2013, Rothstein 2013, Shah et al. 2013, Taylor and Wilfond 2013). The case study analyzed was complicated by the fact that the research study consent forms inadequately covered such scenarios.

Moral duties and obligations related to genetic data and issues of ownership are "collectivized" in the context of genomic data and biobanking. For example, in the research arena, genetic/genomic data may disclose information about an individual's genetic composition that is unrelated to the particular focus of the research study. The ethics of these "incidental" findings is hotly debated (Viberg et al. 2016, Hofmann 2016, Costain and Bassett 2013, Kleiderman et al. 2014, Gliwa and Berkman 2013, Garrett 2013, Borgelt, Anderson, and Illes 2013, Price 2013, Anastasova et al. 2013, Ross and Reiff 2013, Parens, Appelbaum, and Chung 2013, Greenbaum 2014, Appelbaum et al. 2014). The relevance and limitations of the concepts of "duty to rescue" and "right not to know" to incidental findings is also canvassed by many articles (Berkman, Hull, and Biesecker 2015, Zuradzki 2015, Fenwick et al. 2015, Wachbroit 2015, Meagher 2015, Jecker 2015, Garrett 2015, Parsi 2015, Ulrich 2013). Illustratively, Garrett argues that a rescue paradigm grounded in beneficence insufficiently relates to genomics research because the traditional rescue paradigm was developed for short-term situations where risks were unpredictable and unanticipated. Genomics data 
have a much longer horizon and allow for the calculation of statistical probabilities for disease-related harms and thus a duty to rescue paradigm does not apply (Garrett 2015, Ulrich 2013). With respect the notion of "right not to know" Hofman investigated the many arguments for, and against, the right of individuals to remain ignorant of data gleaned from their own genome (2016). These arguments include ones that differentiate types of knowledge, ones that analyze the question in terms of ownership of data, and others that focus on the consequences of disclosure. Hofman holds that individuals "should be able to stay ignorant of incidental findings of uncertain significance" if they so choose (Hofmann 2016, 1).

If data about risks to relatives and progeny speak to the conceptualization of a human as containing data about the future, the incidental findings that Hofman discusses speak to both the individual's present and her future. An interesting case discussing the right not to know and one's present stage was covered by Wiesemann (2011). She uses the case of Caster Semenya, a worldclass runner who was forced to submit to sex verification via genetic testing in order to compete as a female in competitive sports, to argue that individuals have a right to not know their genetically determined biological sex.

The genome contained within humans also stores information about the past. A particularly intriguing piece information that can be uncovered by genomics is paternity. The bioethical debate here hinges on the merits of truth telling in the context of clinical work balanced against duties of non-malfeasance and the respect for individual autonomy. In their article, Adlan and ten Have analyzed the relevance of these concepts in the context of the Islamic faith and Saudi culture where paternity is part biological and part socially-constructed (Adlan and ten Have 2012). At least one commentator felt that disclosure of biological non-paternity in a Muslim context carries the risk of significant harm to the child and mother, thus he advocates for nondisclosure based a duty not to harm (Zabidi-Hussin 2012). Other bioethicists also reflect upon notions of autonomy, data ownership and the regulation of knowledge in the context of direct-to-consumer genetic testing (Bunnik 2015, Hoffman 2016).

In summary a significant proportion of the genethics literature focuses on the regulation of genomic/genetic data. These data are seen as containing inner knowledge about the human being, and are relevant to the individual's relatives and progeny. Underlying the debates about data ownership and protection, the right to know or not know such data, and the moral duties researchers have to patients, research participants, and the wider society is a conceptualization of the human as a source of information about the past, present, and future. 


\section{The Human Being as a Reproductive Organism}

One of the characteristics that distinguish living organisms from non-living matter is their capacity to reproduce. There are two forms of reproduction: asexual and sexual, where sexual reproduction requires bringing together two living organisms. Conventional human reproduction is of the sexual type, and allows for the propagation of genes (and the traits mediated through genes) from parents to their children. Genetic and genomic technologies provide humankind with greater knowledge about, and ability to intervene upon, reproduction. Consequently, these newfound capacities generate bioethical debates about whether we ought to manufacture, and otherwise intervene upon, human reproduction events. Obviously, the genethics literature addressing human reproduction operates out of an ontological view of the human as a reproductive organism. The striking feature of the discourse, however, is that it pushes the conventional limits of human reproduction to debate the facilitation of asexual, and artificial sexual, reproduction.

This literature thus views reproduction not as one of the many essential features of the human being, but rather as a defining characteristic that biomedicine might be morally obligated to service. Furthermore, since successful reproduction among the human species generates biological ties between offspring and progenitors, this subgenre also contends with a host of thorny issues about what constitutes, and what moral duties emerge from, the social construct that lies at the intersection of reproduction and genetic resemblance: parenthood.

Stemming from the idea that members of the human species might have a right to reproduce, Fries comments on a request made by a patient's family to harvest oocytes from their brain-dead family member. Such harvest was, at least in part, argued for on the basis of allowing for the individual's genome to be passed on to others post-death (Fries 2016). Several articles also argue over the moral significance and social ramifications of using genetic technology to assist homosexual couples reproduce. For example, Pennings discusses whether ova donation from one partner to another (ROPA) in lesbian couples is analogous to embryo donation, egg donation or gestational surrogacy (2016). He finds each analogy to be imperfect and argues that "ROPA can be seen not only symbolically but physically creating an equal contribution [to parentage]: one partner becomes the birth mother, and the other the genetic mother." (Pennings 2016, 255).

Scientists also have the ability to create synthetic gametes (ova and sperm) from either component. This technology is particularly useful for gay and lesbian couples as it facilitates the creation of a zygote that contains genes from each of the two partners. As genetic material from the sperm can be used to 
create a synthetic ovum for gay couples and vice versa for lesbian couples, a quasi-natural form of biological reproduction becomes possible. Murphy debunks arguments against synthetic gamete creation for same-sex couples in order to suggest that homosexual individuals have a right to reproduce, and that clinicians are morally bound to assist such reproductive efforts (2014b). The human right to reproduction, notions of parenthood, and their association with genetic resemblance of parent to child is also a central feature in articles discussing the ethics of reproductive cloning and mitochondrial replacement therapies (MRTs) (Harris 2014, Wrigley, Wilkinson, and Appleby 2015, Harris 2015). Reproductive cloning, an asexual form of reproduction not natural to the human species, may be considered to be a useful reproductive technology enabling individuals to reproduce without the need for a partner (genetic or otherwise). On the other hand, MRT is a technique that produces a child with three "parents" since genetic material carried within the mitochondria of a donor ova also becomes part of the zygote. Thus the genetic material in the zygote now comes from the procreative couple as well as the egg donor. As noted above, the idea that parenthood is ascribed solely on genetics is debatable. Furthermore, and with respect to MRT, some bioethicists argue that since the mitochondrial DNA comprises of less than $5 \%$ of the total DNA in the zygote, and because the genes contained therein do not contribute to physical resemblance, a parent relationship among the egg donor and the future child does not issue forth.

Moving from the gamete stage to the zygote and embryo stages, many articles discussed the merits, risks, and morality of pre-implantation and/or pre-natal genetic diagnosis and intervention. A central bioethical question related to the use of these technologies was do aspiring parents have the moral responsibility to produce the "best" children? This concept of procreative or reproductive beneficence was featured in multiple papers. Harris's aforementioned paper on reproductive cloning argues that cloning preserves the human genome more so than any other reproductive method, and should be considered in-line with reproductive beneficence since the ensuing clone would have a "tried and tested" genome (Harris 2014, 58). Other bioethicists carry forth the procreative beneficence argument to IVF and debate whether potential parents who use IVF to reproduce, or who discover abnormalities in their embryo based on prenatal genetic tests, have a moral obligation to insure that their future progeny are free of disability and/or to not select IVF-created embryos that carry disability-like traits (Soniewicka 2015, Weinberger and Greenbaum 2015). In the context of using genetic/genomic technologies to alter the genetic makeup of the to-be-born, Delaney argues that genetic engineering might be morally objectionable (2011). On the basis of Parfit's origin view and a grounds 
for complaint principle, he asserts that genetic engineering modifies a being that has already been "created" from a particular ova and sperm (Delaney 2011). Consequently that being has grounds to complain that they might have been better off in the pre-engineered state.

These ethical concepts were extended to the ethical implications of germline manipulation enabled by CRISPR-Cas 9 technology and MRTs (Harris 2015, Evitt, Mascharak, and Altman 2015). Such technologies change the DNA makeup of all future progeny of the fetus created using them. Accordingly, the genetic pool available to future generations is restricted, as some genes are not allowed to be passed onto future generation. The morality of thus constraining the reproductive "rights" of future generations remains a hot topic of debate. Moving from the clinic to the "free-market," Gynell and Douglas argued that the state has ethical grounds for regulating the use of genetic technology-based selection of traits on the basis of collective action problems that may ensue should the free-market be allowed to operate unrestricted (2015).

The bulk of the discussion about the ethical dimensions of genetic technologies that enable the creation of synthetic gametes and clones, introduce the possibility of different types of genetic linkages between donors of gametes and the embryo produced from such biological material, and allow for the selection of the genetic composition of progeny operates out of the view that members of the human species, in general, are entitled to reproduce. The implicit ontology of the human being, therefore, is one where the human is, in essence, a reproductive living organism. That is not to say that the entire bioethical discussion is focused on the moral duties that emerge from such reproductive rights, or that the assertion of such rights in universally accepted, rather the point here is that the undergirding ontology is one that needs to be unpacked and attended to in order to present a comprehensive moral vision for the use of such technologies.

\section{The Human as a Biologically Evolving Entity}

A third ontology that can help to explain the ethical concepts and questions embedded within the genethics literature is the human as an evolving biologic entity. Evolution, particularly in religious circles, is a particularly controversial topic. Much of the religious debate revolves around speciation, the formation of a new species from prior ones, over the course of time. This idea is not the focus of genethics literature, rather the evolutionary notion here is that the genetic composition of humankind is not static; it is dynamic. As noted above, sexual human reproduction involves the admixing of genetic material from both parents within the nucleus of the zygote. There are many different combinations that can occur and these combinations of parental DNA allow for 
novel genes to be present in the child that are not in the progenitors. Moreover, errors in DNA replication routinely introduce random changes in the cell's DNA, and environmental exposures can also alter one's DNA. Therefore the human genome is not a static entity but is always changing. As new genes can emerge within the human genome, human traits and features may also change. The questions at core of this set of articles revolve around the morality of deliberately changing the genetic profile of adults. If the human gene pool is always changing then using biomedicine to positively influence that change may be morally valid.

Illustratively, Glick discusses the morality of genetic enhancement from a Jewish perspective (2011). He notes that "man is commanded to be co-creator with his Creator in many areas of endeavor" and that Rabbinic authorities state that after the creation of humankind "there remained additional power to create anew, just like people create new animal species through inter-species breeding." (Glick 2011, 417). On the basis of scriptural texts and Rabbinic commentaries, he suggests that there is no "inherent banning of the use of [genetic] techniques for [human] enhancement" in the Jewish tradition (Glick 2011). Some bioethicists find genetic enhancement to be immoral and invoke the concept of human dignity to suggest that humans are part of a natural kind that demands non-interference (and optionally link this concept to a theistic worldview) (Greenbaum 2013, Chan 2015). Other bioethicists push back against such arguments. Chan argues that an Aristotlean view of humanity and ethics supports the usage of genetic technology to enhance human flourishing. He notes that Aristotle held that "a human being reaches its full potential through a combination of nature and nurture" and that "the development of human excellences [is] the goal of human existence."(Chan 2015, 280). One could extend this argument by saying that since the human project involves moral enhancement, therefore using genetic technology for moral enhancement should not be categorically prohibited. Indeed the debate around moral enhancement underlies Murphy's paper on biomoral modification. In it he outlines Persson and Savulescu's views on the moral obligation towards moral enhancement and how differences between individual and societal goals for human enhancement impact the moral assessment of such technologies (Murphy 2015). In another paper Murphy builds out an argument for genetic enhancement by noting that such modification can amplify choices, enrich lives, and consolidate identities (Murphy 2014a).The blurring of the morally important distinction between therapy and enhancement by genetic technologies is also discussed by several articles (Chan 2015, Holtug 2011).

Debates around the ethics of genetic enhancement of the individual or progeny (discussions of genetic intervention on progeny were outlined in the 
previous section) are based on the conceptualization of a human being undergoing constant change in his or her genetic composition. This biological fact is used by proponents of advancement to displace notions of humanity as a static creation, perfect in its nature, and thereby inviolable. Rather they view human nature as a project in development and that there are moral obligations to assist such that the development provided it accords with individual and societal conceptions of the good. An ontological perspective of the human being as an evolving entity informs the subsequent ethical argument for genetic enhancement. Other voices in the literature argue against enhancement but do not squarely challenge this ontological perspective.

\section{Human Ontologies and Their Implications for Islamic Bioethical Perspectives on Genomic and Genetic Technologies}

Our analysis of the genethics literature revealed at least three ontological perspectives on the human that are at the heart of the bioethical discussions- the human being (i) as a source of information about the past, present, and future, (ii) as a reproductive organism, and (iii) as an evolving entity. We hold that Islamic scholars wading into the bioethical debates over genetics and genomics must first assess how these ontologies compare with Islamic theological perspectives on the human being, and subsequently use the instruments of Islamic ethico-legal tradition to craft responses. Below we outline several issues relevant to the reception of these ontologies in the Islamic tradition.

The first ontology sees the human being as a repository of knowledge. Thus we must ask what is the relationship between knowledge and the human being in Islam? A Qur'anic worldview holds that God is the source of all knowledge and that He instructs humankind. Illustratively, the opening story of the Qur'an relates to teacher-learner relationship as God instructs the first human, Adam, about the "names of all things" and is instructed to obey God's commandments (Ali 1999 Verse 2:31). Thus while humans may hold onto knowledge, ultimately it is deemed to originate from God. If information contained in the genome originates from God's knowledge then how do we understand possession and ownership? For example, one might assert that the genomic/genetic data belongs to the individual it was derived from. Alternatively, Islamic scholars might contend that a stewardship responsibility emerges from the idea that humans are but custodians of God's knowledge encoded in the genome. Different legal analyses might therefore proceed from an ownership relationship when compared to a stewardship one. If a particular human "owned" that data then permission and consent might be required prior to any disclosure, however if the relation was of stewardship then God' rights (haqq Allah) over the data can be asserted if the data are of public benefit (mașlahah) (Emon 2006). A re- 
lated question is whether genomic/genetic data is categorically beneficial. The Prophet Muhammad is recorded to have supplicated for beneficial knowledge and protection from knowledge of no benefit (Ibn Mājah Book 34: Hadith 17). How are these categories to be applied to probabilistic data from the genome about the past, present and future? As noted above, bioethicists debate the balancing of a biomedical scientist's responsibility and duty to warn people about disease risks with the individual's right not to know incidental findings. The ways in which the Islamic bioethicists classify genetic/genomic data in terms of its ownership and benefit will surely inform their view on the moral duties related to disclosing and protection these data.

Another related question is whether genetic and genomic data to be treated as certain knowledge in Islam? Science suggests that the genome conveys data about an individual's origin, helps to explain their present state, and forecast probabilities about their future. Islamic logicians define knowledge ( $\mathrm{al}-\mathrm{ilm})$ to be propositional in nature, and consider knowledge to reflect the correspondence between one's understanding of, and true, reality. Accordingly certainty about correspondence between a particular truth claim and reality exists along a spectrum from absolute conviction, yaqin, through predominant certainty ( $>5 \circ \%)$, al-zann al-räjịh and equivocal certainty (50\%), al-shakk, to an improbable conviction, al-zann al-marjūh (Qureshi and Padela 2016). The claims of genetic science regarding the past, present and future would need to be placed into this spectrum prior to making moral assessments. For example how does an Islamic perspective assess DNA evidence? One well-researched example of where genetic claims uneasily fit into Islamic law pertains to claims of paternity. As Shabana and others note even though genetic evidence might reach near certainty it does not negate traditional religious conventions that allow a father to claim paternity (Adlan and ten Have 2012, Shabana 2012, 2013).

In related fashion how do Islamic theologians contend with genetic determinism? And how does genetic knowledge matchup with Islamic theological views about fate, will, destiny and moral responsibility? For example, if the knowledge contained in one's genes reflects God's omniscience one could suggest that it is the "language of God" and contains knowledge about one's fate (Collins 2006). Indeed in our focus group interviews with diverse groups of Muslims, the idea that the genetic code reflects God's destined plan for a person with respect to disease was a dominant theme (Padela 2011). These public understandings merit recognition by scholars providing an Islamic moral vision for genetic and genomic technologies for they reflect the mindset of the technology's end-user.

An ontological perspective of the human as a reproductive organism by nature also bears upon Islamic bioethical positions of genomic and genetic tech- 
nologies. As noted above, genetic technologies have a wide variety of uses in human reproduction. They can help in manufacturing offspring for those who cannot "naturally" reproduce, and can aid in diagnosing and repairing genetic diseases at the prenatal stage. As referenced above, some argue that members of the human species have the right to reproduce and thus the usage of technology to aid reproduction is inherently good. Would an Islamic worldview also contend that having offspring is part of what makes a human, human? A Qur'anic verse seems to suggest that one's biological capacity, as well as the eventual destiny to have children, is part of God's decree. The relevant verse reads "Or He bestows both males and females, and He leaves barren whom $\mathrm{He}$ will.”(Ali 1999 Verse 42:50). On this basis might Islamic theologians interpret infertility among the human population as normative and thus not requiring genetic technologies to "fix"? While much of the Islamic bioethics literature is supportive of using IVF and similar methods to facilitate reproduction in the confines of marriage, do these judgements of permissibility also apply to manufacturing synthetic gametes, manipulating donor ova to accept DNA from other humans, and using reproductive cloning technologies? On one hand, Islamic legists deem having children to be a critically important human interest that Islamic law must protect. So much so that one of the overarching essential higher objectives of Islamic law, maqāșid al-Sharīah, is the preservation of lineage (Raysūnī and International Institute of Islamic Thought. 2005, Shātibī et al. 2011). Indeed the permissibility of using IVF and other biomedical technologies for procreative assistance is often grounded in this objective. As the same time, it is beyond dispute that traditional views on lineage would need to be reimagined to cover the scenarios outlined above. For example, is the moral duty to preserve lineage a relevant construct through which to consider the morality of reproductive cloning? Does mitochondrial DNA create lineal relations according to Islam? Such questions can be better addressed once Islamic theologians reflect on whether reproduction is essential to the human being. If reproduction is deemed essential then perhaps reconceptualization of traditional constructs about lineage in light of new technologies, and the fashioning of detailed ethico-legal views on how to preserve lineage in the present genetic and genomic age is necessary. While Islamic jurists have prohibited gestational surrogacy due to concerns over disturbing traditional notions of lineage, would the ova donor whose cellular material is used in MRT have a claim to parenthood of the future embryo?

In a similar way, genetic and genomic technologies are reconfiguring views on what is means to be a parent, and the attendant moral obligations to the to-be-born. Does procreative beneficence cohere with an Islamic moral vision? While Islamic scriptural sources are replete with references to parents being 
responsible for the moral formation of children, do such responsibilities extend to using genetic selection and/or enhancement technologies on embryos pre- and post-implantation? As some have argued the selection of embryos to implant involves not only choosing who is born but also who is not. How would Islamic theology analyze the role of the human vis-à-vis God in selecting the to-be-born, and how is that reflected into Islamic ethics and law? Ideas such as accepting God's will and dominion versus competing with God's role in creation are often invoked by Islamic scholars discussing biomedical technologies, working out how these concepts relate to human reproduction in the context of genetic and genomic technologies that allow for the selection of traits in one's progeny and even in the future generation of progeny is much needed.

As our ability to modify the genetic composition of individuals and to make germline modifications improves, one wonders if whether we should? This ethical question moves the discussion to the realm of genetic enhancement and brings the notion of a human being as an evolving entity to the fore. Does Islam see the gradual process of human creation as having reached its end, and that the present human being is fully developed biologically? The Qur'an notes that the human is molded by God in the best of forms and Islamic theologians consider humankind to be at the pinnacle of God's creation (Ali 1999 Verse 40:64). Biomedical science and genetic technologies, however, give rise to the ability to modify genotype and the resulting phenotype of individuals and their progeny. Is this modification akin to altering God's creation? With the distinction between therapy and enhancement having been blurred by newfound capacities to intervene upon the human genome, can Islamic theology furnish a clear "red-line" for clinical practice based on this conventional framework? Arguably, an applied ethics must be rooted in theological conceptions of what the human being represents, and in judgements about what aspects of the human being's composition fall under God's sole purview. For example, Islamic legists offer that the Qur'anic prohibition of suicide, in part, stems from a moral condemnation of interfering with God's role as the originator and terminator of life (Yacoub 2001, Sachedina 2004). How are these views about God reconciled in an age when humans can select which embryos to gestate (and which ones not to) and can effect genetic modifications that allow for humanity to gain new, or improve upon existing, moral, physical and other capacities? Glick (2011) finds that Jewish scriptural sources do not categorically prohibit human enhancement, would a reading of the Islamic scriptures offer the same perspective? Moosa's exposition of the varied ways in which scholars have interpreted scriptural texts that appear to warn against the "changing of God's creation" but permit for the cross-pollination of date-palms to determine the illicitness of genetically modified foods, speaks to the need for context- depen- 
dent exegesis in order to delineate moral duties related genetic enhancements (Moosa, 2009).

\section{Final Remarks}

Bioethics sits at the intersection of many fields of knowledge, and has porous disciplinary boundaries. It certainly pertains to the biological sciences as ethical issues pertaining to living organisms are subsumed under the "bio" in the neologism; however conservation of the environment is viewed as part of bioethics as well. The "ethics" portion of the word is also expansive in that encompasses not only the traditional ethical disciplines of philosophy and law (and arguably theology) but politics and sociology as well. Accordingly, the field is marked with multidisciplinary, and a multitude of perspectives are offered on any given moral question.

This variety makes the bioethics discourse a complex one to navigate. For researchers an accurate description of the genre requires recognizing the particular disciplinary vantage points and ethical reasoning modes used by commentators to delineate and analyze the moral dimensions of a problem. For religious scholars seeking to provide moral guidance on a particular bioethical issue, their challenge is compounded by the fact that they need to not only understand the pertinent concepts and relevant ethical perspectives in the field, but also need to deconstruct those concepts and arguments in light of their own tradition prior to lending a religiously informed perspective.

By means of a systematic literature review and qualitative analytic methods this paper aims to help the deconstructive exercise by identifying several ontologies of the human that are implicit to the genethics discourse. We have demonstrated how the relevant bioethical questions as well as the bioethical concepts used to address those questions arise from such conceptualizations of the human being. While our literature search was not exhaustive, and our analytic methods introduce limits on the comprehensiveness with which we can detail specific ontologies, we hold that the developing field of Islamic bioethics must address the ontological claims of biomedicine in addition to the ethical and legal dimensions of the biomedical sciences and practices. Indeed it may be that Islamic theological perspectives on human ontology can supply visions for human flourishing that generate fresh, nuanced, and relevant Islamic bioethical guidance for the present era. 


\section{References}

Adlan, Abdulla. A., and Henk. A. ten Have. 2012. "The dilemma of revealing sensitive information on paternity status in Arabian social and cultural contexts: telling the truth about paternity in Saudi Arabia." J Bioeth Inq 9 (4):403-9. doi: 10.1007/s11673o12-939o-y.

Ali, Abdullah Yusuf. 1999. The Quran Translation. New York: Tahrike Tarsile Quran.

Anastasova, Velizara, Alessandro Blasimme, Sophie Julia, and Anne Cambon-Thomsen. 2013. "Genomic incidental findings: reducing the burden to be fair." AmJ Bioeth 13 (2):52-4. doi: 10.108o/15265161.2012.754066.

Appelbaum, Paul S., Erik Parens, Cameron R. Waldman, Robert Klitzman, Abby Fyer, Josue Martinez, W. Nicholson Price II, and Wendy K. Chung. 2014. "Models of consent to return of incidental findings in genomic research." Hastings Cent Rep 44 (4):22-32. doi: $10.1002 /$ hast.328.

Berkman, Benjamin E., Sara. C. Hull, and Leslie G. Biesecker. 2015. "Scrutinizing the Right Not to Know." Am J Bioeth 15 (7):17-9. doi: 10.108o/15265161.2015.1039733.

Borgelt, Emily, James A. Anderson, and Judy Illes. 2013. "Managing incidental findings: lessons fromneuroimaging." AmJBioeth13 (2):46-7.doi:10.1080/15265161.2012.754069.

Bunnik, Eline. M. 2015. "Do genomic tests enhance autonomy?" JMed Ethics 41 (4):3156. doi: 10.1136/medethics-2014-102171.

Chan, David. K. 2015. "The concept of human dignity in the ethics of genetic research." Bioethics 29 (4):274-82. doi: 10.1111/bioe.12102.

Collins, Francis S. 2006. The language of God: a scientist presents evidence for belief. New York: Free Press.

Corbin, Juliet M., Anselm L. Strauss, and Anselm L. Strauss. 2008. Basics of qualitative research : techniques and procedures for developing grounded theory. 3 rd ed. Los Angeles, California: Sage Publications, Inc.

Costain, Gregory., and Anne. S. Bassett. 2013. "Incomplete knowledge of the clinical context as a barrier to interpreting incidental genetic research findings." AmJ Bioeth 13 (2):58-6o. doi: 10.108 o/15265161.2012.754063.

Crabtree, Benjamin F., and William L. Miller. 1999. Doing qualitative research. 2nd ed. Thousand Oaks, Calif.: Sage Publications.

Delaney, James J. 2011. "Possible people, complaints, and the distinction between genetic planning and genetic engineering." J Med Ethics 37 (7):410-4. doi: 10.1136/ jme.2010.039420.

Dheensa, Sandi, Angela Fenwick, and Anneke Lucassen. 2016. "'Is this knowledge mine and nobody else's? I don't feel that.' Patient views about consent, confidentiality and information-sharing in genetic medicine." Journal of Medical Ethics 42 (3):174-9.

Emon, Anver M. 2006. "Huquq Allah and Huquq Al-Ibad: A Legal Heuristic for a Natural Rights Regime." Islamic Law and Society 13 (3):325-391. 
Evitt, Niklaus H., Shamik Mascharak, and Russ B. Altman. 2015. "Human Germline CRISPR-Cas Modification: Toward a Regulatory Framework." Am J Bioeth 15 (12):259. doi: 10.108 o/15265161.2015.110416o.

Fairclough, Norman. 1995. Critical discourse analysis : the critical study of language, Language in social life series. London; New York: Longman.

Fairclough, Norman. 2009. "A dialectical-relational approach to critical discourse analysis in social research." In Methods of Critical Discourse Analysis, edited by Ruth Wodack and Michael Meyer. London: Sage Publications.

Falagas, Matthew E., Eleni I. Pitsouni, George A. Malietzis, and Georgios Pappas. 2008. "Comparison of PubMed, Scopus, Web of Science, and Google Scholar: strengths and weaknesses." The FASEB Journal 22:338-342.

Fenwick, Angela, Sandi Dheensa, Gillian Crawford, Shiri Shkedi-Rafid, and Anneke Lucassen. 2015. "Rescue obligations and collective approaches: complexities in genomics." Am J Bioeth 15 (2):23-5. doi: 10.1080/15265161.2014.990763.

Fries, Melissa. 2016. "Analysis: OB/GYN-Genetics." J Clin Ethics 27 (1):59-6o.

Garrett, J. R. 2013. "Reframing the ethical debate regarding incidental findings in genetic research." Am J Bioeth 13 (2):44-6. doi: 10.1080/15265161.2013·757972.

Garrett, Jeremy R. 2015. "Collectivizing rescue obligations in bioethics." Am J Bioeth 15 (2):3-11. doi: 10.1080/15265161.2014.990163.

Glick, Shimon M. 2011. "Some Jewish thoughts on genetic enhancement." J Med Ethics 37 (7):415-9. doi: 10.1136/jme.2009.034744.

Gliwa, Catherine, and Benjamin E. Berkman. 2013. "Do researchers have an obligation to actively look for genetic incidental findings?" Am J Bioeth 13 (2):32-42. doi: $10.1080 / 15265161.2012 .754062$.

Greenbaum, Dov. 2013. "If you can't walk the walk, do you have to talk the talk: ethical considerations for the emerging field of sports genomics." Am J Bioeth 13 (10):19-21. doi: $10.1080 / 15^{26} 6161.2013 .828121$.

Greenbaum, Dov. 2014. “If you don't know where you are going, you might wind up someplace else: incidental findings in recreational personal genomics." AmJ Bioeth 14 (3):12-4. doi: 10.108o/15265161.2013.879946.

Gyngell, Chris, and Thomas Douglas. 2015. "Stocking the genetic supermarket: reproductive genetic technologies and collective action problems." Bioethics 29 (4):24150. doi: 10.1111/bioe.12098.

Harris, John. 2014. "Time to exorcise the cloning demon." Camb Q Healthc Ethics 23 (1):53-62. doi: 10.1017/Sog63180113000443.

Harris, John. 2015. "Germline Manipulation and Our Future Worlds." Am J Bioeth 15 (12):30-4. doi: 10.108 o/15265161.2015.1104163.

Hoffman, Sharona. 2016. "The Promise and Perils of Open Medical Data." Hastings Cent Rep 46 (1):6-7. doi: 10.1002/hast.529.

Hofmann, Bjørn. 2016. "Incidental findings of uncertain significance: To know or not to 
know--that is not the question." BMC Med Ethics 17:13. doi: 10.1186/s12910-016-oog62.

Holtug, Nils. 2011. "Equality and the treatment-enhancement distinction." Bioethics 25 (3):137-44. doi: 10.1111/j.1467-8519.2009.0175o.x.

Ibn Mājah, Abū 'Abdillāh Muḥammad ibn Yazīd. Sunan Ibn Majah. Sunnah.com

Jecker, Nancy S. 2015. "Rethinking rescue medicine." Am J Bioeth 15 (2):12-8. doi: 10.108o/15265161.2014.990169.

Kleiderman, Erika, Bartha M. Knoppers, Conrad V. Fernandez, Kym M. Boycott, Gail Ouellette, Durhane Wong-Rieger, Shelin Adam, Julie Richer, and Denise Avard. 2014. "Returning incidental findings from genetic research to children: views of parents of children affected by rare diseases." JMed Ethics 40 (10):691-6. doi: 10.1136/medethics-2013-101648.

Meagher, Karen M. 2015. "Seeking context for the duty to rescue: contractualism and trust in research institutions." Am J Bioeth 15 (2):18-20. doi: 10.1080/15265161.2014.990170.

Miles, Matthew B., and A. Michael Huberman. 1994. Qualitative data analysis : an expanded sourcebook. 2nd ed. Thousand Oaks: Sage Publications.

Milner, Lauren C., Emily Y. Liu, and Nanibaa' A. Garrison. 2013. “Relationships matter: ethical considerations for returning results to family members of deceased subjects.” Am J Bioeth 13 (10):66-7. doi: 10.108o/15265161.2013.828533.

Moosa, Ebrahim. 2009. "Genetically Modified Foods and Muslim Ethics." In Acceptable Genes? Religious Traditions and Genetically Modified Foods, edited by Conrad G. Brunk and Harold Coward, 135-157. Albany: State University of New York Press.

Murphy, Timothy F. 2014a. "Genetic modifications for personal enhancement: a defence." JMed Ethics 40 (4):242-5. doi: 10.1136/medethics-2012-101026.

Murphy, Timothy F. 2014b. "The meaning of synthetic gametes for gay and lesbian people and bioethics too." JMed Ethics 40 (11):762-5. doi: 10.1136/medethics-2013-101699. Murphy, Timothy F. 2015. "Preventing ultimate harm as the justification for biomoral modification." Bioethics 29 (5):369-77. doi: 10.1111/bioe.12108.

Padela, Aasim, Katie Gunter, and Amal Killawi. 2011. Meeting the Healthcare Needs of American Muslims: Challenges and Strategies for Healthcare Settings. Washington DC: Institute for Social Policy \& Understanding.

Parens, Erik, Paul Appelbaum, and Wendy Chung. 2013. "Incidental findings in the era of whole genome sequencing?" Hastings Cent Rep 43 (4):16-9. doi: 10.1002/hast.189.

Parsi, Kayhan. 2015. "Rethinking the rescue paradigm." Am J Bioeth 15 (2):1-2. doi: 10.1080/15265161.2015.1006o31.

Pellegrino, Edmund D., and David C. Thomasma. 1981. A philosophical basis of medical practice : toward a philosophy and ethic of the healing professions. New York: Oxford University Press.

Pennings, Guido. 2016. "Having a child together in lesbian families: combining gestation and genetics." JMed Ethics 42 (4):253-5. doi: 10.1136/medethics-2015-103007. 
Price, W. Nicholson II. 2013. "Legal implications of an ethical duty to search for genetic incidental findings." Am J Bioeth 13 (2):48-9. doi: 10.1080/15265161.2012.754068.

Qureshi, Omar, and Aasim I. Padela. 2016. "When must a patient seek healthcare? Bringing the perspectives of islamic jurists and clinicians into dialogue." Zygon 51 (3):592-625. doi: 10.1111/zygo.12273.

Raysūnī, Ahmad, and International Institute of Islamic Thought. 2005. Imam al-Shatibi's theory of the higher objectives and intents of Islamic law. London ; Washington: International Institute of Islamic Thought.

Ross, Kathryn M., and Marian Reiff. 2013. "A perspective from clinical providers and patients: researchers' duty to actively look for genetic incidental findings." AmJ Bioeth 13 (2):56-8. doi: 10.108 o/15265161.2012.754064.

Rothstein, Mark A. 2013. "Should researchers disclose results to descendants?" Am J Bioeth 13 (10):64-5. doi: 10.1080/15265161.2013.828531.

Sachedina, Abdulaziz. 2004. "Islamic Bioethics." The Annals of Bioethics: Religious Perspectives in Bioethics:153-171.

Shabana, Ayman. 2012. "Paternity between Law and Biology: The Reconstruction of the Islamic Law of Paternity in the wake of DNA Testing." Zygon 47 (1):214-239.

Shabana, Ayman. 2013. "Negation of Paternity in Islamic Law between Li'ān and DNA Fingerprinting." Islamic Law and Society 20 (3):157-201

Shah, Seema K., Sara C. Hull, Michael A. Spinner, Benjamin E. Berkman, Lauren A. Sanchez, Ruquyyah Abdul-Karim, Amy P. Hsu, Reginald Claypool, and Steven M. Holland. 2013. "What does the duty to warn require?" Am J Bioeth 13 (10):62-3. doi: $10.108 \mathrm{o} / 15^{26} 6161.2013 .8285^{28}$.

Shāṭibī, Ibrāhīm ibn Mūsá, Imran Ahsan Khan Nyazee, Raji M. Rammuny, Centre for Muslim Contribution to Civilization., and Qatar Foundation. 2011. The reconciliation of the fundamentals of Islamic law. 1st ed, Great books of Islamic civilization. Reading, UK: Garnet Pub.

Soniewicka, Marta. 2015. "Failures of Imagination: Disability and the Ethics of Selective Reproduction." Bioethics 29 (8):557-63. doi: 10.1111/bioe.12153.

Strauss, Anselm L., and Juliet M. Corbin. 1998. Basics of qualitative research: techniques and procedures for developing grounded theory. 2nd ed. Thousand Oaks: Sage Publications.

Taylor, Holly A., and Benjamin S. Wilfond. 2013. "The ethics of contacting family members of a subject in a genetic research study to return results for an autosomal dominant syndrome." Am J Bioeth 13 (10):61. doi: 10.108o/15265161.2013.828523.

Tiemersma, Douwe. 1987. "Ontology and ethics in the foundation of medicine and the relevance of Levina's view." Theor Med 8 (2):127-33.

Ulrich, Michael. 2013. "The duty to rescue in genomic research." Am JBioeth 13 (2):50-1. doi: 10.108 o/15265161.2012.754067.

Viberg, Jennifer, Pär Segerdahl, Sophie Langenskiold, and Mats G. Hansson. 2016. "Free- 
dom of Choice About Incidental Findings Can Frustrate Participants' True Preferences." Bioethics 30 (3):203-9. doi: 10.1111/bioe.1216o.

Wachbroit, Robert. 2015. "Rescue, strangers, and research participants." Am J Bioeth 15 (2):21-2. doi: 10.1080/15265161.2014.990759.

Weaver, Meaghann. 2016. "The Double Helix: Applying an Ethic of Care to the Duty to Warn Genetic Relatives of Genetic Information." Bioethics 30 (3):181-7.

Weinberger, Sara, and Dov Greenbaum. 2015. "Genetic technology to prevent disabilities: how popular culture informs our understanding of the use of genetics to define and prevent undesirable traits." Am J Bioeth 15 (6):32-4. doi: 10.108 o/15265161.2015.1028665.

Wiesemann, Claudia. 2011. "Is there a right not to know one's sex? The ethics of 'gender verification' in women's sports competition." JMed Ethics 37 (4):216-20. doi: 10.1136/ jme.2010.039081.

Wodack, Ruth, and Michael Meyer. 2009. "Critical Discourse Analysis: history, agenda, theory and methodology." In Methods of Critical Discourse Analysis, edited by Ruth Wodack and Michael Meyer. London: Sage Publications.

Wrigley, Anthony, Stephen Wilkinson, and John B. Appleby. 2015. "Mitochondrial Replacement: Ethics and Identity." Bioethics 29 (9):631-8. doi: 10.1111/bioe.12187.

Yacoub, Ahmed A. 2001. The Fiqh of Medicine. London: Ta-Ha Publishers Ltd.

Zabidi-Hussin, Z. A. 2012. "Does nondisclosure of genetic paternity status constitute a breach of ethics?: Commentary on "The dilemma of revealing sensitive information on paternity status in Arabian social and cultural contexts" by Abdallah A. Adlan and Henk A. M. J. ten Have." J Bioeth Inq 9 (4):413-4. doi: 10.1007/s11673-012-9401-z.

Żuradzki, Tomasz. 2015. «The preference toward identified victims and rescue duties.» Am J Bioeth 15 (2):25-7. doi: 10.108o/15265161.2014.990168. 